\title{
HUBUNGAN SAGITTAL ABDOMINAL DIAMETER (SAD) DENGAN TEKANAN DARAH PADA PENDERITA OBESITAS
}

\author{
Ni Kadek Yuni Lestari ${ }^{1}$, Komang Upadana Putra ${ }^{2}$ \\ 1, Departemen Keperawatan Medikal Bedah STIKes Wira Medika Bali \\ 2, Program Studi Ilmu Keperawatan STIKes Wira Medika Bali \\ *Email: yunilestariwika@gmail.com
}

\begin{abstract}
Abstrak
Penumpukan jaringan lemak yang berlebih di dalam tubuh yang merupakan faktor terjadinya aterosklerosis. Aterosklerosis pada pembuluh darah akan menyebabkan penyempitan pada pembuluh darah arteri sehingga aliran darah menjadi tidak lancar atau terjadi peningkatan resistensi pembuluh darah yang memicu terjadinya hipertensi. Sagittal Abdominal Diameter (SAD) merupakan pengukuran antropometri yang memiliki korelasi paling kuat dan signifikan terhadap abdominal fat dibandingkan dengan pengukuran antropometri lain. Tujuan penelitian ini untuk mengetahui hubungan Sagittal Abdominal Diameter dengan tekanan darah pada penderita obesitas. Metode : Jenis penelitian deskriptif korelasional dengan rancangan cross-sectional study. Jumlah sampel 107 orang dipilih dengan teknik purposive sampling. Alat yang digunakan untuk mengukur $S A D$ adalah Abdominal Caliper. Hasil : Rerata ukuran SAD adalah 26,01 termasuk abdominal fat meningkat. Rerata tekanan darah pada penderita obesitas yaitu sistole $146,73 \mathrm{mmHg}$ dan diastole 90,56 mmHg. Analisa : Hasil uji Correlation Product Moment didapatkan nilai $p$ value sebesar $0,000(<0,05)$ menunjukkan ada hubungan Sagittal Abdominal Diameter dengan tekanan darah pada penderita obesitas. Diskusi: penumpukan lemak pada daerah abdomen menyebabkan menurunnya kadar adiponektin, menurunkan asam lemak bebas sehingga memicu terjadinya resistensi insulin. Keadaan hiperinsulinemia ini dapat menyebabkan vasokonstriksi dan reabsorpsi natrium di ginjal yang pada akhirnya mengakibatkan hipertensi.
\end{abstract}

Kata kunci : Sagittal Abdominal Diameter, Tekanan Darah, Obesitas

\begin{abstract}
Correlation of Sagittal Abdominal Diameter (SAD) With Blood Pressure In Obese Patients Introduction: Excess of fat tissue in the body a factor of atherosclerosis. Atherosclerosis in the blood vessels will cause narrowing of the arteries so that blood flow is not smooth or an increase in blood vessel resistance that triggers the occurrence of hypertension. Sagittal Abdominal Diameter (SAD) is an anthropometric measurement that has the strongest and most significant correlation to abdominal fat compared with other anthropometric measurements. The purpose of this study to determine the relationship of Sagittal Abdominal Diameter with blood pressure in obese people. Method: Type of correlational descriptive study with cross-sectional design. The sample was 107 people selected by purposive sampling technique. The tool used to measure SAD is the Abdominal Caliper. Result: The mean SAD was 26.01 including abdominal fat increased. Average blood pressure in obese people is sistole 146,73 $\mathrm{mmHg}$ and diastole 90,56 $\mathrm{mmHg}$. Analiysis: The result of Correlation Product Moment p value of $0.000(<0,05)$ this result show there is relationship of Sagittal Abdominal Diameter with blood pressure in obese patient. Discussion: fat accumulation in the abdominal area decreases adiponectin levels, lowering free fatty acid intake can trigger insulin resistance. This hyperinsulinemia state can lead to vasoconstriction and reabsorption of sodium in the kidney, which in turn leads to hypertension.
\end{abstract}

Keywords: Sagittal Abdominal Diameter, Blood Pressure, Obesity 
Lestari, Ni Kadek Yuni, \& Putra, Komang Upadana. Hubungan Sagittal Abdominal Diameter (SAD) Dengan Tekanan Darah Pada Penderita Obesitas. Journal of Borneo Holistic Health, Vol.3, No. 1 Juni 2020 hal 34-47

\section{Pendahuluan}

Kemajuan

zaman

menyebabkan perubahan dalam gaya hidup masyarakat. Perubahan gaya hidup telah mempengaruhi pola makan dan kesehatan. Masyarakat cenderung lebih menyukai makanan siap saji yang kandungan gizinya tidak seimbang. Pola makan yang salah dengan cepat dapat menimbulkan keadaan kegemukan atau obesitas (Anwar \& Khomsan, 2013).

Obesitas menduduki peringkat kelima dalam faktor resiko masalah kardiovaskuler (Hanata dan Freitag, 2014). Peningkatan lemak tubuh (obesitas) berhubungan dengan peningkatan tekanan darah melalui berbagai mekanisme, baik secara langsung maupun tidak langsung, secara langsung obesitas dapat menyebabkan peningkatan cardiac output karena makin besar massa tubuh makin banyak pula jumlah darah yang beredar sehingga curah jantung ikut meningkat. Sedangkan secara tidak langsung melalui perangsangan aktivitas sistem saraf simpatis dan Renin Angiotensin Aldosteron System (RAAS) oleh mediator-mediator seperti hormon, sitokin, adipokin. Salah satunya adalah hormon aldosteron yang terkait erat dengan retensi air dan natrium sehingga volume darah meningkat (Sulastri, 2012).

Prevalensi hipertensi di dunia pada tahun 2016 menurut World Health Organization (WHO) pada penduduk umur $>18$ tahun mencapai 1 milliar orang, dengan kasus hipertensi tertinggi berada di Afrika sebanyak $46 \%$ sedangkan prevalensi terendah terdapat di Amerika yaitu 35\%. Data Profil Kesehatan Indonesia tahun 2016, menunjukkan prevalensi hipertensi di Indonesia sebesar 26,5 persen. Prevalensi hipertensi di Bali menempati peringkat keenam terbanyak kasus hipertensi yaitu sebanyak 29,1\%, (Depkes RI, 2016). Data Profil Kesehatan Kesehatan Provinsi Bali, jumlah penderita hipertensi diseluruh Kabupaten di Bali pada tahun 2015 sebanyak 10.295 orang. Jumlah penderita hipertensi meningkat pada tahun 2016 sebanyak 12.886 orang, dimana Kota Denpasar merupakan jumlah kasus tertinggi di Bali sebanyak 3110, kemudian Kabupaten Tabanan dengan jumlah kasus sebanyak $2976 \quad$ sementara 
Kabupaten Badung berada di tempat ketiga kasus hipertensi terbanyak dengan jumlah kasus 2580 (Dinas Kesehatan Provinsi Bali, 2016). Jumlah penderita hipertensi terbanyak terdapat di wilayah kerja Puskesmas II Denpasar Utara dengan jumlah penderita sebanyak 612 orang dengan jumlah kunjungan pasien hipertensi perbulan rata-rata sebanyak 80 orang dengan rentang usia 30-75 (Dinas Kesehatan Kota Denpasar, 2016).

Menurut penelitian Puspitasari (2014), salah satu cara mudah untuk mendeteksi seseorang menderita hipertensi adalah dengan mengukur indikator obesitas. Salah satu indikator obesitas yang paling akurat ialah pengukuran Sagittal Abdominal Diameter (SAD). SAD merupakan pengukuran antropometri yang memiliki korelasi paling kuat dan signifikan terhadap abdominal fat dibandingkan dengan pengukuran antropometri lain seperti IMT dan lingkar pinggang (Pimentel et al, 2010). Kriteria obesitas dengan pengukuran SAD yaitu jika hasil > $25 \mathrm{~cm}$. SAD lebih dari $25 \mathrm{~cm}$ menunjukan abdominal fat meningkat yang menunjukkan seseorang mengalami obesitas abdominal. Tingginya konsentrasi lemak di dalam tubuh dapat beresiko tinggi terjadinya hipertensi. Selain lemak mengakibatkan obesitas, gumpalan lemak bisa mempersempit pembuluh darah. Lemak yang menempel di pembuluh darah dapat mengakibatkan aliran darah menjadi tidak lancar sehingga terjadi peningkatan tekanan darah (Idrus, 2014).

Salah satu upaya yang sudah dilakukan Puskesmas II Denpasar Utara dalam mencegah penyakit tidak menular (PTM) khususnya angka kejadian hipertensi dimasyarakat salah satunya melaksanakan kegiatan Posbindu yang dilaksanakan dibanjar binaan Puskesmas II Denpasar Utara secara terstruktur setiap satu bulan sekali dengan kegiatan penyuluhan kesehatan, pemeriksaan kesehatan serta olaharaga senam. Disamping itu penanganan awal terhadap faktor resiko hipertensi juga merupakan hal yang sangat penting dalam mencegah kejadian hipertensi, salah satunya pada indikator berat badan berlebih yang dapat memicu terjadinya 
kejadian hipertensi khususnya pada usia dewasa.

Berdasarkan data obesitas tahun 2018 usia $\geq 18$ tahun yang melibatkan wilayah kerja Puskesmas II Denpasar Utara yaitu Pemecutan Kaja, Kelurahan Ubung dan Desa Ubung Kaja, didapatkan sebanyak 351 orang mengalami obesitas. Masyarakat yang mengalami obesitas tertinggi terdapat di Desa Pemecutan Kaja yaitu sebanyak 251 orang terdiri dari 106 laki-laki dan 145 perempuan. Berdasarkan studi pendahuluan pada tanggal 25 Pebruari 2018 di Desa Pemecutan Kaja terhadap 10 orang penduduk yang berusia 30-50 tahun terdiri dari 6 perempuan dan 4 laki-laki dengan melakukan pengukuran antropometri lingkar pinggang yang dilakukan dengan mengukur keliling perut melalui pertengahan krista iliaka dengan tulang iga terbawah secara horizontal, didapatkan hasil sebanyak 7 orang mengalami obesitas sentral yaitu 3 laki-laki dengan lingkar perut $\geq 90 \mathrm{~cm}$ dan 4 orang perempuan dengan lingkar perut $\geq 80 \mathrm{~cm}$. Peneliti melakukan pengukuran tekanan darah terhadap 7 orang yang mengalami obesitas sentral didapatkan hasil 4 orang dengan tekanan darah sistole lebih dari 140 $\mathrm{mmHg}$ dan diastole diatas $90 \mathrm{mmHg}$. Berdasarkan uraian di atas mendorong peneliti untuk mengadakan penelitian tentang hubungan Sagittal Abdominal Diameter (SAD) dengan tekanan darah pada kasus obesitas di Desa Pemecutan Kaja Wilayah Kerja Puskesmas II Denpasar Utara.

\section{Metode}

Jenis penelitian ini adalah deskriptif korelasional dengan pendekatan cross sectional (Nursalam, 2013).

Pengambilan data dilakukan di Desa Pemecutan Kaja Wilayah Kerja Puskesmas II Denpasar Utara pada bulan Juni 2018. Sampel dalam penelitian ini adalah penduduk wanita yang mengalami obesitas yang memenuhi kriteria inklusi sebanyak 107 orang dengan purposive sampling. Analisa data mengunakan uji Pearson Product Moment. 
Lestari, Ni Kadek Yuni, \& Putra, Komang Upadana. Hubungan Sagittal Abdominal Diameter (SAD) Dengan Tekanan Darah Pada Penderita Obesitas. Journal of Borneo Holistic Health, Vol.3, No. 1 Juni 2020 hal 34-47

\section{Hasil}

\section{Karakteristik subyek penelitian}

\begin{tabular}{|c|c|c|c|}
\hline \multicolumn{2}{|c|}{$\begin{array}{l}\text { Tabel 1 } \\
\text { Responden } \\
\text { Pekerjaan }\end{array}$} & $\begin{array}{l}\text { Distribusi } \\
\text { Berdasarkan }\end{array}$ & \begin{tabular}{rr}
\multicolumn{2}{c}{ Frekuensi } \\
an & Jenis
\end{tabular} \\
\hline $\mathbf{N}$ & Pekerjaa & \multicolumn{2}{|c|}{ Hasil Penelitian } \\
\hline $\mathbf{o}$ & $\mathbf{n}$ & Frekuensi & Persentase \\
\hline 1 & Swasta & 69 & 64.5 \\
\hline 2 & $\begin{array}{l}\text { Wiraswast } \\
\text { a }\end{array}$ & 29 & 27.1 \\
\hline 3 & PNS & 9 & 8.4 \\
\hline & Total & 107 & 100,0 \\
\hline
\end{tabular}

menunjukkan bahwa karakteristik

responden berdasarkan pekerjaan,

sebagian besar yaitu sebanyak 69

responden $(64,5 \%)$ karyawan swasta.

Tabel 2 Frekuensi Status perkawinan

\begin{tabular}{clcc}
\hline N & Status & \multicolumn{2}{c}{ Hasil Penelitian } \\
\cline { 3 - 4 } o & Perkawinan & Frekuensi & Persentase \\
\hline 1 & Menikah & 107 & 100,0 \\
2 & Tidak & 0 & 0 \\
3 & Janda/Duda & 0 & 0 \\
\hline & Total & 107 & 100,0 \\
\hline
\end{tabular}

Berdasarkan tabel di atas, menunjukkan bahwa karakteristik responden berdasarkan status perkawinan, semuanya $(100 \%)$ menikah.

Tabel 2 Distribusi Frekuensi Responden Berdasarkan Kebiasaan Merokok

\begin{tabular}{|c|c|c|c|}
\hline \multirow[b]{2}{*}{$\begin{array}{l}\mathbf{N} \\
\mathbf{0}\end{array}$} & \multirow{2}{*}{$\begin{array}{l}\text { Kebiasaan } \\
\text { Merokok }\end{array}$} & \multicolumn{2}{|c|}{ Hasil Penelitian } \\
\hline & & $\begin{array}{c}\text { Frekuens } \\
\text { i }\end{array}$ & $\begin{array}{c}\text { Persenta } \\
\text { se }\end{array}$ \\
\hline 1 & $\begin{array}{l}\text { Tidak } \\
\text { merokok }\end{array}$ & 97 & 90.7 \\
\hline 2 & Merokok & 10 & 9.3 \\
\hline & Total & 107 & 100,0 \\
\hline
\end{tabular}

menunjukkan bahwa karakteristik responden berdasarkan kebiasaan merokok, sebagian besar yaitu 97 orang $(90,7 \%)$ tidak merokok.

\section{Hasil Pengamatan Terhadap Variabel Penelitian}

\section{Sagittal Abdominal Diameter (SAD)}

Tabel 3 Hasil Pengamatan Variabel Sagittal Abdominal Diameter (SAD)

\begin{tabular}{|c|c|c|c|c|c|}
\hline & Mean & $\underset{n}{\text { Media }}$ & SD & Min & $\begin{array}{l}\mathbf{M} \\
\mathbf{a k}\end{array}$ \\
\hline $\begin{array}{l}\text { Sagittal } \\
\text { Abdomina } \\
\text { l Diameter } \\
(S A D)\end{array}$ & 26,01 & 26 & 4,894 & 16 & 39 \\
\hline
\end{tabular}

Berdasarkan tabel diatas menunjukkan rerata ukuran Sagittal Abdominal Diameter (SAD) adalah 26,01 termasuk abdominal fat meningkat yang menunjukkan seseorang mengalami obesitas abdominal, dengan nilai minimum 16 dan maksimum 39.

2. Tekanan darah pada penderita obesitas

Tabel 4 Hasil Pengamatan Variabel Tekanan Darah

\begin{tabular}{lccccc}
\hline $\begin{array}{l}\text { Tekana } \\
\text { n }\end{array}$ & $\begin{array}{c}\text { Mean Media } \\
\text { Darah }\end{array}$ & SD & Min & Mak \\
\hline $\begin{array}{l}\text { Hasil } \\
\text { Sistole }\end{array}$ & 146,73 & 150 & 27,188 & 90 & 195 \\
$\begin{array}{l}\text { Hasil } \\
\text { Diastole }\end{array}$ & 90,56 & 90 & 13,181 & 65 & 120 \\
\hline
\end{tabular}

Berdasarkan tabel diatas

menunjukkan rerata tekanan darah pada penderita obesitas yaitu sistole 146,73 $\mathrm{mmHg}$ dan diastole 90,56 $\mathrm{mmHg}$ termasuk mengalami 
hipertensi tahap 1, dengan nilai minimum sistole 90 , diastole 65 dan maksimum sistole 195 dan diastole 120.

\section{Hasil Analisis Data}

Tabel 5 Hasil Uji Normalitas Data

SAD dan Tekanan Darah

\begin{tabular}{lcccc}
\hline & N & $\begin{array}{l}\text { Mea } \\
\mathbf{n}\end{array}$ & SD & $\begin{array}{l}\mathbf{p} \\
\text { value }\end{array}$ \\
\hline $\begin{array}{l}\text { Sagittal } \\
\text { Abdominal } \\
\text { Diameter } \\
(\text { SAD })\end{array}$ & 107 & 26,01 & 4,894 & 0,106 \\
$\begin{array}{l}\text { Tekanan } \\
\text { darah } \\
\text { systole }\end{array}$ & 107 & 146,73 & 27,188 & 0,166 \\
$\begin{array}{l}\text { Tekanan } \\
\text { darah } \\
\text { diastole }\end{array}$ & 107 & 90,56 & 13,181 & 0,121 \\
\hline
\end{tabular}

Berdasarkan hasil uji normalitas menggunakan uji OneSample Kolmogorov-Smirnov Test didapatkan nilai $p$ value SAD sebesar 0,106 tekanan darah systole 0,166 dan tekanan darah diastole 0,121 dimana nilai $\mathrm{p}$ value $>0,05$ ini menunjukan bahwa data berdistribusi dengan normal.

Teknik analisa data yang digunakan untuk menguji hipotesis dengan menggunakan uji Korelasi product moment. Analisis data dilakukan untuk menganalisis hubungan Sagittal Abdominal Diameter (SAD) dengan tekanan darah pada penderita obesitas di Desa Pemecutan Kaja Wilayah Kerja
Puskesmas II Denpasar Utara. Hasil analisisnya adalah seperti terdapat pada tabel dibawah ini :

\begin{tabular}{|c|c|c|c|}
\hline Variable & $\mathrm{N}$ & $\begin{array}{c}\mathrm{p} \\
\text { value }\end{array}$ & $\begin{array}{l}\text { Coeffecient } \\
\text { correlation }\end{array}$ \\
\hline $\begin{array}{l}\text { SAD- } \\
\text { Tekanan } \\
\text { Darah } \\
\text { Sistolik }\end{array}$ & 107 & 0,000 & 0,764 \\
\hline $\begin{array}{l}\text { SAD- } \\
\text { Tekanan } \\
\text { Darah } \\
\text { Diastolik }\end{array}$ & 107 & 0,000 & 0,814 \\
\hline
\end{tabular}

Berdasarkan hasil uji Product Moment SAD dengan tekanan darah sistolik dab diastole didapatkan nilai $p$ value sebesar 0,000 $(<0,05)$. Hasil ini menunjukkan ada hubungan yang signifikan Sagittal Abdominal Diameter (SAD) dengan tekanan darah pada penderita obesitas di Desa Pemecutan Kaja Wilayah Kerja Puskesmas II Denpasar Utara. Nilai koefisiensi kolerasi sistolik sebesar 0,764 dan diastolik sebesar 0,814 menunjukkan variabel Sagittal Abdominal Diameter (SAD) dengan tekanan darah memiliki derajat hubungan kuat dan sangat kuat serta arah hubungan antar variabel terdapat hubungan yang positif atau searah artinya semakin tinggi Sagittal Abdominal Diameter (SAD) 
maka tekanan darah akan semakin tinggi.

\section{Pembahasan}

\section{Sagittal Abdominal Diameter (SAD)}

Hasil penelitian menunjukkan rerata ukuran Sagittal Abdominal Diameter (SAD) adalah 26,01 termasuk abdominal fat meningkat yang menunjukkan seseorang mengalami obesitas abdominal, dengan nilai minimum 16 dan maksimum 39. Responden pada penelitian ini mengalami obesitas abdominal dapat dipengaruhi oleh karakteristik responden salah satunya umur. Umur responden pada penelitian ini seluruhnya 30-50 tahun. Hasil penelitian ini ini didukung oleh Kurniawan (2013) menyatakan bahwa pada usia 30-50 tahun seseorang cenderung mengalami obesitas dibandingkan dengan usia yang lebih muda. Perubahan umur berkaitan dengan peningkatan dalam distribusi jaringan lemak yang ditandai dengan meningkatnya lingkar pinggang seseorang serta memiliki hubungan dengan terjadinya perubahan dalam komposisi tubuh seseorang.
Pada usia dewasa yaitu rentang umur 30-50 tahun seseorang cenderung mengalami obesitas sentral dibandingkan dengan umur yang lebih muda. Hal ini diduga karena lambatnya metabolisme, kurangnya aktivitas fisik, dan frekuensi konsumsi pangan yang lebih sering. Selain itu, orang tua biasanya tidak begitu memperhatikan ukuran tubuh.

Jenis kelamin juga dapat mempengaruhi terjadinya obesitas sentral. Pada penelitian ini responden semuanya perempuan. Menurut Kurniawan (2013) prevalensi obesitas khususnya obesitas sentral lebih tinggi ditemukan pada perempuan dibandingkan pada lakilaki. Hal ini disebabkan karena adanya perbedaan tingkat aktivitas fisik dan asupan energi pada laki-laki dan perempuan. Perempuan cenderung lebih berisiko obesitas sentral, terutama ketika memasuki umur 45 tepatnya saat menopause. Perempuan menopause atau post menopause memiliki persentase lemak perut, kolesterol total, dan trigliserida yang tinggi. Seiring dengan bertambahnya umur dan efek menopause, pada perempuan akan 
terjadi peningkatan kandungan lemak tubuh, terutama distribusi lemak tubuh pusat.

Pekerjaan juga dapat mempengaruhi terjadinya obesitas sentral. Pada penelitian ini responden sebagian besar sebagai pegawai swasta. Terjadinya obesitas pada pekerja swasta, hal ini berkaitan dengan tingkat aktivitas Menurut Sudargo (2014) yang mengatakkan perubahan pada struktur sosial berhubungan dengan peningkatan obesitas. Hubungan ini terletak pada peningkatan proporsi populasi pekerjaan dalam bidang pelayanan, perkantoran, dan profesi lain yang kurang aktivitas fisik jika dibandingkan dengan pekerjaan manual yang membutuhkan banyak aktivitas fisik pada masyarakat tradisional.

Status perkawinan, dimana responden pada penelitian ini semuanya menikah. Menurut Kurniawan (2013) obesitas berhubungan nyata positif dengan status kawin, prevalensi obesitas tertinggi pada orang yang memiliki status cerai dan terendah pada orang yang belum menikah. Penelitian Hamid (2014) yang meneliti tentang faktor-faktor yang berhubungan dengan obesitas sentral ditemukan prevalensi obesitas sentral pada responden sebesar 49,7\%, dimana $55,8 \%$ terjadi pada kelompok umur 30-50 tahun.

Peneliti berpendapat, hasil penelitian yang menunjukkan rerata ukuran Sagittal Abdominal Diameter (SAD) termasuk abdominal fat meningkat yang menunjukkan seseorang mengalami obesitas abdominal, dapat disebabkan karena asupan energy dari makanan yang selalu melebihi energi yang dipergunakan oleh tubuh, yang terjadi dalam jangka waktu tertentu, menimbulkan akumulasi (penumpukan) jaringan lemak tubuh secara berlebihan dan kelebihan jaringan lemak ini menyebabkan peningkatan lingkar pinggang

\section{Tekanan darah pada penderita obesitas}

Hasil penelitian menunjukkan rerata tekanan darah pada penderita obesitas yaitu sistole $146,73 \mathrm{mmHg}$ dan diastole $90,56 \mathrm{mmHg}$ termasuk mengalami hipertensi tahap 1, dengan nilai minimum sistole 90 , diastole 65 dan maksimum sistole 195 dan diastole 120. Menurut 
Triyanto (2014) meningkatnya jumlah penyakit degeneratif salah satunya adalah peningkatan jumlah kejadian penyakit hipertensi salah satu penyebabnya adalah kemajuan dan perkembangan teknologi di era globalisasi ini, menimbulkan dampak yang signifikan terhadap perubahan gaya hidup, dan pola makan pada masyarakat modern khususnya didaerah perkotaan. Masyarakat saat ini lebih cenderung mengkonsumsi makanan siap saji, minuman berakohol, merokok serta kurangnya melakukan aktivitas fisik.

Tekanan darah responden dalam kategori hipertensi tahap 1 dapat disebabkan oleh karakteristik responden yaitu umur dan jenis kelamin dimana responden pada penelitian ini seluruhnya wanita dan berumur 30-50 tahun. Menurut Triyanto (2014) prevalensi terjadinya hipertensi pada laki-laki sama dengan wanita. Hipertensi mulai terjadi pada laki-laki pada usia dewasa atau dimulai ketiak memasuki umur 31 tahun. Tetapi lebih banyak menyerang wanita ketika memasuki usia 45 tahun, sekitar $60 \%$ penderita hipertensi terjadi pada wanita. Hal ini sering dikaitkan dengan penurunan hormon estrogen pada wanita yang sudah mengalami menopause. Berkurangnya hormon estrogen dapat menambah resiko sindrom metabolisme. Sindrom metabolisme merujuk pada banyaknya gejala abnormal dan memusat dalam tubuh wanita termasuk tekanan darah tinggi, obesitas sentral dan keabnormalan lemak darah.

Seiring bertambahnya umur, maka tekanan darah juga akan meningkat. Setelah umur 45 tahun, dinding arteri akan mengalami penebalan oleh karena adanya penumpukan zat kolagen pada lapisan otot, sehingga pembuluh darah akan berangsur-angsur menyempit dan menjadi kaku. Tekanan darah sistolik meningkat karena kelenturan pembuluh darah besar yang berkurang pada penambahan umur sampai dekade ketujuh sedangkan tekanan darah diastolik meningkat sampai dekade kelima dan keenam kemudian menetap atau cenderung menurun. Peningkatan umur akan menyebabkan beberapa perubahan fisiologis, pada usia lanjut terjadi peningkatan resistensi perifer dan 
aktivitas simpatik. Pengaturan tekanan darah yaitu refleks baroreseptor pada usia lanjut sensitivitasnya sudah berkurang, sedangkan peran ginjal juga sudah berkurang dimana aliran darah ginjal dan laju filtrasi glomerulus menurun (Smeltzer, S, \& Bare, 2008).

Hasil penelitian yang didapat didukung oleh penelitian yang dilakukan oleh Natalia (2014) tentang hubungan obesitas dengan kejadian hipertensi di Kecamatan Sintang, Kalimantan Barat. Hasil penelitian menunjukkan sebanyak 76 $(54,7 \%)$ responden menderita hipertensi. Penelitian Febriyani (2016) tentang hubungan indeks massa tubuh dengan kejadian hipertensi pada perempuan postmenopause di Kecamatan Denpasar Barat. Hasil penelitian dari sejumlah 47 sampel perempuan postmenopause, didapatkan 25 orang menderita hipertensi (tekanan darah $\geq 140 / 90 \mathrm{mmHg}$ ) sementara sisanya yaitu sejumlah 22 orang termasuk nonhipertensi (tekanan darah < 140/90 mmHg).

Menurut pendapat peneliti, kejadian hipertensi selaian disebabkan oleh faktor umur dan jenis kelamin dapat juga dipengaruhi oleh faktor konsumsi makanan. Dewasa ini, telah terjadi pergeseran dari konsumsi makanan tradisional yang banyak mengandung karbohidrat dan serat sekarang menjadi lebih banyak konsumsi makanan masyarakat barat yang mengandung banyak protein, lemak, dan garam tetapi kurang serat. Tingginya asupan makanan yang mengandung energi dalam bentuk karbohidrat dan lemak, serta garam dapat mempengaruhi tinggi rendahnya tekanan darah dalam tubuh sehingga menyebabkan terjadinya hipertensi. Disamping faktor konsumsi makanan faktor aktivitas fisik juga dapat mempengaruhi kejadian hipertensi.

\section{Hubungan Sagittal Abdominal} Diameter (SAD) dengan tekanan darah pada penderita obesitas

Hasil penelitian didapatkan nilai $p$ value sebesar $0,000(<0,05)$, menunjukkan ada hubungan Sagittal Abdominal Diameter (SAD) dengan tekanan darah pada penderita obesitas di Desa Pemecutan Kaja Wilayah Kerja Puskesmas II Denpasar Utara. Nilai koefisiensi kolerasi sistolik sebesar 0,764 dan 
Lestari, Ni Kadek Yuni, \& Putra, Komang Upadana. Hubungan Sagittal Abdominal

Diameter (SAD) Dengan Tekanan Darah Pada Penderita Obesitas. Journal of Borneo

Holistic Health, Vol.3, No. 1 Juni 2020 hal 34-47

diastolik sebesar 0,814 menunjukkan variabel Sagittal Abdominal Diameter (SAD) dengan tekanan darah memiliki derajat hubungan sangat kuat dan arah hubungan antar variabel terdapat hubungan yang positif atau searah artinya semakin normal Sagittal Abdominal Diameter (SAD) maka tekanan darah akan semakin normal

Hasil penelitian ini didukung oleh Sulastri. (2012) menyatakan obesitas sentral dapat memicu terjadinya hipertensi. Hal ini terjadi karena pada obesitas sentral penumpukan lemak lebih banyak pada daerah abdomen. Berlebihnya lemak pada abdomen dapat menyebabkan beberapa hal diantaranya: menurunkan kadar adiponektin, menurunkan ambilan asam lemak bebas intrasel oleh mitokondria sehingga oksidasi berkurang, dan menyebabkan akumulasi asam lemak bebas intrasel. Kelebihan asam lemak bebas dapat memicu terjadinya resistensi insulin. Keadaan hiperinsulinemia ini dapat menyebabkan vasokonstriksi dan reabsorpsi natrium di ginjal, yang pada akhirnya mengakibatkan hipertensi

Jaringan lemak yang berlebih dalam tubuh merupakan faktor terjadinya aterosklerosis dimana terjadi penimbunan lemak pada pembuluh darah yang disebut atheroma. Aterosklerosis pada pembuluh darah akan menyebabkan aliran darah menjadi tidak lancar atau terjadi peningkatan resistensi pembuluh darah. Untuk meningkatkan aliran darah kerja pompa jantung ditingkatkan. Arteri yang mengalirkan darah ke luar dari jantung, harus menahan tekanan yang tinggi ketika darah dipompakan ke luar (Smeltzer, S, \& Bare, 2008).

Hasil penelitian ini sesuai dengan teori Wargahadibrata (2013) yang menyatakan mekanisme yang mengakibatkan hipertensi oleh karena obesitas meliputi peningkatan overaktivitas simpatik yang berhubungan dengan peningkatan lemak visceral pada perut. Aktivitas simpatik yang meningkat akan merangsang pelepasan renin dan pembentukan angiotensin II yang secara tidak langsung meningkatkan produksi aldosteron dari kelenjar adrenal sehingga menyebabkan 
retensi sodium. Peningkatan lemak visceral berhubungan dengan peningkatan pelepasan mediator inflamasi, stres oksidatif, dan penurunan vasodilatasi endotelial pembuluh darah.14 Peningkatan tekanan darah setelah menopause dilaporkan memiliki asosiasi secara signifikan dengan faktor obesitas. Hal ini sehubungan dengan hormon estrogen yang merupakan antioksidan kuat sebagai penghambat Reactive Oxygen Species (ROS) dan peningkatan bioavailibitas Nitric Oxide (NO). Berkurangnya estrogen pada perempuan postmenopause mengakibatkan peningkatan IMT atau kejadian obesitas sehingga perempuan postmenopause cenderung mengalami peningkatan tekanan darah atau hipertensi.

Peneliti berpendapat kelebihan lemak (hiperlipidemia), dapat menimbulkan penimbunan lemak di sepanjang pembuluh darah. Akibatnya aliran darah menjadi kurang lancar sehingga berpotensi mengalami penyumbatan darah sehingga suplai oksigen dan zat makanan kedalam tubuh terganggu. Penyempitan dan sumbatan oleh lemak ini memacu jantung untuk memompa darah lebih kuat lagi agar dapat memasok kebutuhan darah ke jaringan. Akibatnya, tekanan darah meningkat, maka terjadilah hipertensi. Penderita yang kelebihan berat badan atau obesitas, tubuhnya bekerja keras untuk membakar kelebihan kalori yang masuk. Pembakaran kalori ini memerlukan suplai oksigen dalam darah yang cukup.Semakin banyak kalori yang dibakar, semakin banyak pula pasokan oksigen dalam darah. Banyaknya pasokan darah tentu menjadikan jantung bekerja lebih keras dampaknya tekanan darah orang yang obesitas cenderung tinggi.

\section{Kesimpulan}

Rerata ukuran Sagittal Abdominal Diameter (SAD) adalah 26,01 termasuk abdominal fat meningkat yang menunjukkan seseorang mengalami obesitas abdominal, dengan nilai minimum 16 dan maksimum 39.

Rerata tekanan darah pada penderita obesitas yaitu sistole 146,73 $\mathrm{mmHg}$ dan diastole 90,56 $\mathrm{mmHg}$ termasuk mengalami hipertensi tahap 1, dengan nilai minimum sistole 90 , diastole 65 dan 
maksimum sistole 195 dan diastole 120.

Hasil analisis menggunakan correlation product moment didapatkan nilai $p$ value sebesar $0,000 \quad(<0,05)$ menunjukkan ada hubungan Sagittal Abdominal Diameter (SAD) dengan tekanan darah pada penderita obesitas di Desa Pemecutan Kaja Wilayah Kerja Puskesmas II Denpasar Utara

\section{Referensi}

Anwar \& Khomsan. (2013). Makanan Tepat Badan Sehat. Jakarta: Hikmah

Dinas Kesehatan Kota Denpasar. (2016). Profil Kesehatan Kota Denpasar. Denpasar : Dinas Kesehatan Denpasar

Dinas Kesehatan Provinsi Bali. (2016). Profil Kesehatan Provinsi Bali. Denpasar : Dinkes Bali

Hamid. (2014). Faktor-Faktor Yang Berhubungan Dengan Obesitas Sentral Pada Penduduk Dewasa (30-50 Tahun) Dikecamatan Lubuk Sikaping. (online), available: http//www.scribd.com/doc/606 40456, (28 Pebruari, 2018).

Hanata dan Freitag. (2014). Karakteristik kegemukan pada anak sekolah dan remaja di Medan dan Jakarta Selatan. (online), available: http//www.scribd.com/doc/606 40456, (21 Pebruari, 2018).

Idrus. (2014). Reaktivitas Kardiovaskuler Individu Normotensi Dari Orang Tua
Hipertensi Primer. Jurnal Kardiologi Indonesia.

Kurniawan. (2013). Hubungan Indeks Massa Tubuh Dengan Tingkat Kesegaran Jasmani Pada Anak. Tesis. Fakultas Kedokteran Universitas Diponegoro.

Natalia. (2014). Hubungan Obesitas Dengan Kejadian Hipertensi di Kecamatan Sintang, Kalimantan Barat. (online), available:

http//www.scribd.com/doc/606 40456, (21 Pebruari, 2018).

Nursalam. (2013). Konsep dan Penerapan Metodelogi Penelitian Ilmu Keperawatan, Pedoman Skripsi, Tesis, dan Instrumen Penelitian Keperawatan, Edisi 2, Jakarta : Salemba Medika

Pimentel et al, (2010). Accuracy of Sagittal Abdominal Diameter As Predictor Of Abdominal Fat Among Brazilian Adults: a Comparation With Waist Circumference. Online https://pdfs.semanticscholar.or $\mathrm{g}$

Puspitasari. (2014). Hipertensi Dengan Obesitas: Adakah Peran Endotelin? Departemen Kardiologi dan Kedokteran Vaskular, Fakultas Kedokteran Universitas Indonesia Pusat Jantung Nasional, Harapan Kita, Jakarta : Jurnal Kardiologi Indonesia • Vol. 28, No. $6 \bullet$ November 2014.

Smeltzer, S, \& Bare. (2008). Brunner $\&$ Suddarths Textbook of Medical Surgical Nursing. Philadelpia : Lippin cott

Sudargo. (2014). Obesitas:

Permasalahan dan Terapi Praktis. Jakarta : CV Sagung Seto. 
Lestari, Ni Kadek Yuni, \& Putra, Komang Upadana. Hubungan Sagittal Abdominal Diameter (SAD) Dengan Tekanan Darah Pada Penderita Obesitas. Journal of Borneo Holistic Health, Vol.3, No. 1 Juni 2020 hal 34-47

Sulastri. (2012). Faktor - Faktor Yang Berhubungan Dengan Obesitas Sentral Pada Wanita Dewasa (30 - 50 Tahun) Di Kecamatan Lubuk Sikaping Tahun 2008. Jurnal Kesehatan Masyarakat. (online) available :http://ejournal.ac.id/index.php/ jnursing. Diperoleh tanggal 2 Pebruari 2018

Triyanto. (2014). Pelayanan Keperawatan Bagi Penderita Hipertensi Secara Terpadu. Jakarta : Graha Ilmu

Wargahadibrata, A.F. (2013). Kelebihan Berat Badan dan Berat Badan Berlebih (Obesitas). Jakarta: PT Gramedia Pustaka Utama.

WHO. (2007). Facts Related to Cronic Disease: Non Communicable Disease Prevention and Health Promotion. (online). Available from:http://www.who.int.

Diperoleh tanggal 2 Pebruari 2017 